\title{
Simone de Beauvoir and Lesbian Lived Experience
}

There is a large family of things we know and need to know about ourselves and each other with which we have, as far as I can see, so far created for ourselves almost no theoretical room to deal.

EVE KOSOFSKY SEDGWICK ${ }^{1}$

I'd be careful about saying any woman had no consciousness.

JOAN NESTLE ${ }^{2}$

Every act of becoming conscious

(it says here in this book)

is an unnatural act

ADRIENNE RICH ${ }^{3}$

On the first International Women's Day of the new millennium, I walked across the small midwestern campus where I work to sit sipping punch with a miscellaneous group of people. The sweet-tempered woman leading our discussion asked each of us to name one woman who had inspired us, whose life we wanted to celebrate on this special occasion. Most of those present, ranging from an earnest sophomore girl to the campus rabbi, a man in his seventies, said, "my mother." I named Rosa Luxemburg — a lie, but I wanted Socialism to be at least mentioned ... Only one person named Simone de Beauvoir: H., the music librarian, whose self-description when we'd first met had been as a lesbian, but who by the time of this discussion was transitioning from female to male.

The Second Sex was a strange, unwieldy book to begin with, and it seems to get stranger all the time; Beauvoir still means a lot to people, but just what she means keeps changing. When I asked H. "why Beauvoir?" he referred to Judith Butler, then got a little nervous: "I need to sit down and really read The Second Sex," he said; "I've never actually done that." That reaction has become very familiar to me over the several decades I've been working on Beauvoir.

1 Eve Kosofsky Sedgwick, The Epistemology of the Closet, 24.

2 Joan Nestle, remark made during discussion of The Feminist Memoir Project: Voices from Women's Liberation, Columbia University Seminar on Woman and Society, New York City, May 17, 1999.

3 Rich, "The Phenomenology of Anger," 169. 
People seem to attribute a profound, even a life-changing, significance to Simone de Beauvoir even when they have not read a word she wrote. Her name stands for some kind of deep unsettling (in the good sense), unhooking, undermining, kicking loose: things, as it turns out, are not, or at least do not have to be, as Mother said they were; what you've always suspected was going on underneath the everyday human comedies of gender, is in fact there, and everywhere.

At the same time Beauvoir has been a target for disappointment and anger.

The first time I read The Second Sex was around 1981, in a graduate literature seminar at Columbia co-taught by Carolyn Heilbrun and Nancy Miller. I didn't understand the book, I didn't understand why it was important to them that we read it, and I totally hated it. Partly I think I was blaming the messenger: that my oppression was that deep, that total, was not something I wanted to know. The parts I hated most, though, were the parts about sex, especially the chapter titled "La lesbienne." Oddly, some of the same parts that then furnished me with reasons for utterly dismissing her now seem to me the backbone of Beauvoir's project, and a good second starting-point for my argument: that it is worth reading Beauvoir, that she is less wrong about many things than has generally been supposed, and that reading The Second Sex with attention to time, both the time of its writing and the different times of its readings, helps us better understand what she meant, and discover what we can still use.

But then, coming out in my early twenties, with the theory wars dividing Columbia's English department and the sex war starting across the street, I had a checklist of myths to distrust: arrested development, mother-daughter patterns, inversion, butch-femme roles, masculine protest, anything to do with Sigmund Freud. All these myths seemed to be repeated in Beauvoir. None of them had anything to do with me: I was me, and I was in love, for my own reasons, many of which had to do with feminism. I also had a deep, deep suspicion of seeing lesbians marshalled as symbols or allegories in the texts of straight women. ${ }^{4}$

I was not alone. Many American lesbian feminists have found Beauvoir's chapter "La lesbienne" ("The Lesbian") problematic, from the 1970s on: it provides no "positive role models," appears to include biologistic explanations, and cites such discredited authorities as the rather bizarre Wilhelm Stekel (see chapter 1 above). And who is "la lesbienne," the lesbian, anyhow? The definite article certainly dates the chapter theoretically, in the same way Beauvoir's use of "la femme" (Woman) and "elle" (she) throughout the book does. This, plus

4 See Altman, "How Not To Do Things with Metaphors We Live By." This was before the 1990 publication of Beauvoir's Lettres à Sartre complicated what we knew about her love life. 
her seeming failure to take the position about "inversion" we thought was the correct one-that there was no such thing, that same-sex love had nothing at all to do with a desire to be the opposite gender-made us think she couldn't possibly be a social constructionist after all. Then there was the way she drew on literary texts we did not think much of, such as the poems of Renée Vivien, as though they had a nonfiction, documentary authority. And finally there was her overt disdain for the idea of lesbians and/or homosexuals organizing themselves as a political movement.

But this may be a good time to look again. Beauvoir's view that lesbian lives may be lived in many different ways, that gender "inversion" and object choice are not necessarily related but sometimes may be, does not look so retrograde in this age of "queer," of the revaluation of bisexuality, of new transgender possibilities and subjectivities. Her contentions that lesbianism, like heterosexuality, like anything else, may be lived either in bad faith or in authenticity, depending on the way it is chosen, and that the body matters, but doesn't determine us, may, as Toril Moi has argued, be helpful in formulating a conception of agency feminism can use. ${ }^{5}$

But why were we originally angry and embarrassed, rather than simply dismissive? We found in that text neither a mirror nor a model, and yet some ideas there seemed familiar enough that we resented an intrusion: how dare she talk about my private things in this way I don't quite recognize? It was a bit like Freud's uncanny, or the existentialist Look of the Other which steals from me my position as center of the world, as subject. Now I wonder whether I was at that time so concerned to stress the ordinary normality of my life that I was unnerved by the very ideas, terms, and images that might now be praised as resistance to normalization of the female body. Rereading with the understanding that, as I discussed above, feminism at any period will be inextricably entwined with other contemporary ways of seeing women and sex, that, as Foucault tells us, the discourses of repression and liberation can't be pried apart, ${ }^{6}$ I see something rather different. In the early 1980 s, my classmates and I found Beauvoir's discussion of lesbian sexuality both heterodox and incoherent, which it was, and is ... but this no longer strikes me as such a bad thing.

Much of the work done on Beauvoir and lesbianism has been biographical. Here, as in the first chapter, I will continue to sideline that approach, by which I don't mean to suggest it isn't important; but I think the way many generations of women have read her life looking for either reassuring mirrors or hopeful models, and then often reacted to what they found out with disappointment or

5 See Toril Moi, What is a Woman? 3-120.

6 Foucault, History of Sexuality, 95-101. 
even rage, doesn't help us remember to read her work and listen to what she actually says. This is just as true for "the lesbian question" as it has been for the question of the success or failure of her lifelong relationship with Sartre. ${ }^{7}$

But those less familiar with Beauvoir may still want at least a seat-of-thepants answer to the question, "Was she a lesbian?" One can't answer this question, and one can't not answer it, either. Let me just say that the world is divided into people for whom the question has a simple one-word answer, and those for whom it does not; Beauvoir is in the latter category.

She was certainly accused of being a lesbian at least three times. First, during the phony war of 1939-40, when her journal records that her friend Stepha "interrogated" her one day (in the Café Dôme) "to find out whether I was really a piège." ${ }^{8}$ Second, during the German occupation of France, she was fired from her teaching job on the basis of an accusation of "détournement de mineur" (corruption of a minor) brought (with some accuracy, if little justice) by the mother of one of her students, Nathalie Sorokine, an incident she masks in her autobiography. ${ }^{9}$ And third, charges that Beauvoir was a lesbian figured in the stream of logically inconsistent vilification with which such established French literary figures as François Mauriac greeted the publication of The Second Sex: "Frustrated, frozen, priapic, nymphomaniac, a lesbian, a hundred times

7 Both issues have been entangled with posthumous revelations and with questions about public versus private presentations of self. Responses have ranged from the hagiographic to the wounded to the passive-aggressive. Useful discussions include Margaret Simons, "Lesbian Connections"; Jeffner Allen, "A Response to a Letter from Peg Simons, December 1993"; Hazel Barnes, "La lesbienne."

8 "Je me suis assise à côté d'elle et elle m'a interrogée pour savoir si j'étais vraiment piège; on a lu le journal, regardé Marie-Claire qui donne des modèles de lettres aux soldats à se fendre la pipe.... " Beauvoir, Journal de guerre, 88. Piège is short for "piège-à-loups," literally "wolf trap" or "man trap." Apparently this phrase was used to describe a homosexual person of either sex by Beauvoir's friend Mme. Morel, who seems to have invented it. I have not seen it used by anyone outside the Sartre circle, nor have I yet succeeded in getting any French person to recognize it. As Margaret Simons notes ("Lesbian Connections," 122-26), Beauvoir did not record her reply to Stepha, nor did she mention this conversation in her letter to Sartre detailing her day; but both journals and letters for the period suggest it was a question she was asking herself.

9 Although Beauvoir covers up the content of the charge, her comment there is interesting: "Before the war, the matter would have ended there; with the clique of Abel Bonnard [a reactionary Minister of Education installed by the German occupiers] it happened otherwise; at the end of the school year, the headmistress with the blue chin informed me that I was excluded from the University" (which is to say, banned from teaching in the public sector). [Avant-guerre, l'affaire n'eût pas eu de suite; avec la clique d'Abel Bonnard, il en alla autrement; à la fin de l'année scolaire, la directrice au menton bleu me signifia que j'étais exclue de l'Université (La force de l'âge [hereinafter FA], 617).] 
aborted: I was accused of everything, even of having an illegitimate child"10_ the French version of the nympho-lesbo-killer-whore, with additional charges of frigidity, abortion, and out-of-wedlock motherhood. ${ }^{11}$ And since her death she has been accused both of being a lesbian and of not being one, sometimes in the same breath.

What else can I say? - that she had a number of very important loving relationships with women early and late in life, which may or may not have been sexual; that she had sexual contact with women, at least through the early 1940s, in ways that may or may not have been loving; ${ }^{12}$ that she never said she was a lesbian; and that she had her homophobic moments-like most people.

\section{Where the Lesbians Are}

It's helpful, as always, to keep the basic structure of Beauvoir's argument in mind. The first volume, "Les faits et les mythes," performs a series of moves that unsettle any naturalized notion of femininity as essence and expose men's view of women as "Other" as a disabling mystification. The second volume, titled "L'expérience vécue," takes us through women's life cycle under present conditions of education and society. ${ }^{13}$ Beauvoir describes "la femme" as she is, but "what we must understand is the range of the verb 'to be" - as Bill Clinton once put it, it all depends on what the meaning of the word "is" is.

We find this vicious circle in all such circumstances. When an individual or a group of individuals is kept in a situation of inferiority, the fact is that

10 "Insatisfaite, glacée, priapique, nymphomane, lesbienne, cent fois avortée, je fus tout, et même mère clandestine." She continues: "People [wrote and] offered to cure me of my frigidity, or to satisfy my monstrous appetites; they promised the filthiest revelations, but in the name of the True, the Beautiful, the Good, and even of Poetry, all of which I had outraged." [On m'offrait de me guérir de ma frigidité, d'assouvir mes appétits de goule, on me promettait des révélations, en termes orduriers, mais au nom du vrai, du beau, du bien, de la santé et même de la poésie, indignement saccagés par moi ( $F C h$ 1:260-61).] See also Ingrid Galster, Le deuxième sexe de Simone de Beauvoir: Mémoire de la Critique, and Moi, Making of an Intellectual Woman.

11 So, if as Didier Eribon says in Réflexions sur la question gay, "l'injure" (the insult, the curse) is the beginning of gay identity....

12 Perhaps the best description of this period was her own, much later, in a letter to Nelson Algren: "I happened to behave very badly," she wrote (A Transatlantic Love Affair: Letters to Nelson Algren, 135).

13 "Après la plupart de mes affirmations il faut sous-entendre 'dans l'état actuel de l'éducation et des mœurs.' Il ne s'agit pas ici d'énoncer des vérités éternelles mais de décrire le fond commun sur lequel s'enlève toute existence féminine singulière" ( $D S$ 2:9). 
he, or it, is inferior; but what we must understand is the range of the verb "to be": bad faith consists in giving it the value of a static substance, when it has the dynamic Hegelian meaning: to be is to have become, to have been made what one now shows oneself to be. ${ }^{14}$

Nothing about what women are like now has any necessary implications for, or deep claim upon, what the women of tomorrow could be, and if you refuse to recognize this, if instead you pile up reasons why nothing can change and why you can't change, you're guilty of bad faith. As Adrienne Rich put it, "Only she who says / she did not choose, is the loser in the end."15

But I tell my students to write this point on an index card and keep it in front of them while they read the rest of the book, because it is very easy to lose track of, in the welter of detail about how women under present conditions of culture and society do, in Beauvoir's view, happen alas to be. Many chapters and sub-arguments in The Second Sex take the form of a sandwich, with problematically essentialist or essentializing filling between slices of social constructionist bread. In her chapter on biology, for example, after reminding us that a woman is not the same thing as an ovary and that it is a long way from the egg to the woman, she leads us through a tortured discussion of the sperm, the egg, and animal behavior from anaerobes to us, before telling us that none of it much matters because "man" is not a natural species but a cultural idea-the body is the instrument of our grasp on the world; the body is a situation, which we may choose to live freely or otherwise. ${ }^{16}$

"So why didn't she just say so, and spare us what all those stupid scientists said?" the annoyed student wants to know. Apparently the project to "understand everything" and "say everything" that Beauvoir conceived in adolescence did not issue in systems-building (as it did for Sartre) but in a dislike of leaving anything out. ${ }^{17}$ I've been arguing, though, that this is actually a strength: the encyclopedic piling up of seemingly everything available on a topic corrects for the philosopher's habit of categorical statement, opens up spaces to think

14 "On retrouve ce cercle vicieux en toutes circonstances analogues: quand un individu ou un groupe d'individus est maintenu en situation d'infériorité, le fait est qu'il est inférieur; mais c'est sur la portée du mot être qu'il faudrait s'entendre; la mauvaise foi consiste à lui donner une valeur substantielle alors qu'il a le sens dynamique hégélien: être c'est être devenu, c'est avoir été fait tel qu'on se manifeste" ( $D S$ 1:25). This passage develops from an analogy between the situation of women and the situation of Blacks, which I'll explore in my later chapters.

15 Rich, "Twenty-One Love Poems," 244.

16 See Fallaize, "A Saraband of Imagery."

17 MJFR 335. 
in that a tighter argument might have foreclosed, makes it possible to engage with the thickness, the depth, the ambiguity of the lived world.

But as with The Golden Notebook, the structure of The Second Sex is integral to the argument. The chapter titled "La lesbienne" occurs in the middle of the section on women's life cycle, but lesbian experience and feeling in The Second Sex are not confined to that chapter. Rather, lesbian existence is diffused throughout, as perfectly ordinary, only to be expected, even something any rational woman, if not deformed by her culture, might well prefer. The opening pages of the first chapter, "Enfance," tell us that both boys and girls begin by desiring their mothers; ${ }^{18}$ a bit later we hear that the garçon manqué (tomboy) is only rebelling against the social constraints that deny her the human right to actively possess the world..$^{19}$ According to the next chapter, "La jeune fille" (the young girl), another form of adolescent reluctance to go along with the conventional vocation féminine can be found in schoolgirl romances, which are described at length with reference to Mädchen in Uniform, Emily Dickinson's letters, and the novels of Colette and Rosamund Lehmann, alongside psychoanalytic and sexological narratives. ${ }^{20}$ Then, when it comes time for "Linitiation sexuelle" (Sexual Initiation, by which Beauvoir means heterosexual initiation), women have a lot to overcome: for one thing, male flesh is resistant and repulsive compared to the more familiar sensation of touching a woman's smooth body; ${ }^{21}$ there is often not much distinction between a woman's first heterosexual penetration and rape; ${ }^{22}$ and finally, it is difficult for a woman, who is a free desiring subject and a human being grasping the world, to resign herself to the sexual passivity and dependence involved in "becoming a woman." ${ }^{23}$ Readers might be forgiven for concluding that lesbian feeling is more basic, or at least more obvious, that it is heterosexuality that must be learned, very often in fear and trembling. "If we must speak of nature, one might say that naturally every woman is lesbian." ${ }^{4}$

That heterosexuality has to be learned is a big part of Beauvoir's central contention throughout her second volume. I've argued in chapter 1 that her long catalog of things that can go wrong for the young girl, the adolescent, the married woman, which are often difficult to read or even disgusting and have led

\footnotetext{
18 DS 2:13-14.

$19 D S$ 2:50-51.

$20 \quad D S$ 2:108-13.

$21 \quad D S$ 2:154-55, 191.

$22 \quad D S$ 2:148, 162-63.

$23 \quad D S$ 2:165, 195-98.

24 "[S]i l'on invoque la nature, on peut dire que naturellement toute femme est homosexuelle" (DS 2:195).
} 
some readers to say Beauvoir "didn't like women," is in fact making this point: the development of "patriarchal femininity," as Moi helpfully calls it, is a wrenching experience; 25 the process of becoming a "woman" deforms you. The crisis of adolescence, Beauvoir says, is a travail, a "work," comparable to the work of mourning described by psychoanalysis. ${ }^{26}$ Showing this is part of showing that it is a process: it's not natural or inborn, and thus, it could be otherwise. At one time, I was bothered by her description of same-sex affection as a phase or stage because I took this to mean she was minimizing its authenticity, by reinscribing it within normative heterosexuality. But now it strikes me as a key move in her unsettling of heterosexual "development," which is so far from obvious, so bizarre, in fact, that the explanation for it must involve social power.

Is the chapter on "La lesbienne," as Ursula Tidd has said, marginalized by its placement within the life cycle of "the woman"?27 There are two ways to see this. Volume 2 has four parts, "Formation," "Situation," "Justifications," and "Vers la libération." "La lesbienne" is at the end of the "Formation" section, poised on the cusp of adulthood, between "Linitiation sexuelle" and "La femme mariée" (The Married Woman) - two chapters that contain the densest and most awful descriptions of rotten heterosexual sex in the book. The lesbian chapter is not in section 4, "Towards Liberation," which has only one chapter, "La femme indépendante," but things could be worse. At least it's not in the third section, "Justifications," with its protracted jeremiads against three life paths women can take in complicitous bad faith: "La narcissiste," "L'amoureuse" (The Woman in Love), and "La mystique." "La lesbienne" is taken as part of the life cycle, part of ordinary development, and yet, there she also is, as herself.

\section{Reading in Time}

It is curious to me now that around the same time I was learning to detest Beauvoir's view of lesbians, I was very much liking Adrienne Rich's "Compulsory Heterosexuality and Lesbian Existence," which first appeared in Signs in 1980 , and which makes what now seems a very similar point: why would women ever turn from loving women to loving men unless they were forced to? Rich never mentions Beauvoir by name in that essay, but the word "existence" in her title now jumps out at me, as does the word "phenomenology" in her

\footnotetext{
25 Moi, Making of an Intellectual Woman, 190-94.

26 DS 2:140.

27 Ursula Tidd, "Le deuxième sexe, la conscience noire et la conscience lesbienne," 75.
} 
poem, "The Phenomenology of Anger," from which one of the epigraphs to this chapter is taken. ${ }^{28}$ For those of us trying to do work on lesbians within women's studies, itself a fledging field, Rich's essay was tremendously helpful, not least because her "lesbian continuum" seemed to offer a way out of the mulberry bush game of " $\mathrm{X}$ was a lesbian? You can't prove that, so we won't approve your dissertation topic." 29 But I also remember vigorously defending "Compulsory Heterosexuality" against the anxiety and anger of heterosexual feminists who resented being told that their own sexual choices were not authentic or feminist enough and that they were not entitled to want what they felt they wanted.

I have now taught the essay to mainly heterosexual undergraduates of both sexes approximately fifty times, and have learned to deal with this issue a bit more tactfully. Rich doesn't actually say that heterosexuality can't be a genuine choice, but she never suggests that it can. It's still a real issue and a hard one to discuss without resurrecting that old existentialist term, "authenticity."30 The

28 For a reading of Beauvoir through the lens of Rich's argument, see Simons, "Lesbian Connections." Rich herself explains her terms as follows: "Lesbian existence suggests both the fact of the historical presence of women and our continuing creation of the meaning of that existence" - italics mine, to indicate a very Beauvoirian turn of thought. It is interesting as well that in the exchange of letters about this essay Rich reprinted alongside it in Blood Bread and Poetry (1986), the editors of Powers of Desire question, among other concepts, the term "false consciousness" - in some ways, another version of "bad faith." Perhaps this marks the historical moment when both terms left the lexicon of feminist theory, probably for perfectly good reasons, but not without loss (see Moi, What is a Woman). Also, like Beauvoir, Rich begins her argument by turning psychoanalysis against itself, by using the evidence it uncovers to expose its tacit normativity. (Rich's particular target is Nancy Chodorow.)

Beauvoir's legacy to Rich and other early lesbian-feminists is complex. For instance, Lillian Faderman uses the term "existentialist lesbians" to refer to what were more often called "political lesbians" or "women-identified-women," when they weren't being called by worse names (Odd Girls and Twilight Lovers, 207, 269). Why existentialist? Rich signals her indebtedness to Beauvoir most clearly in Of Woman Born; when she said, in the famous talk reprinted in On Lies Secrets and Silence, "[i]t is the lesbian in us who is creative, for the dutiful daughter of the fathers in us is only a hack" — she must have been thinking of Beauvoir's Mémoires d'une jeune fille rangée, which was translated as Memoirs of a Dutiful Daughter. But what was she thinking - that Beauvoir had stopped short of this insight about lesbians? That she had had it in spite of herself?

29 This seems quaint now even to me, although it wasn't much fun at the time. De mortuis nil nisi bonum.

30 Interestingly, GLBTQ politics seems to be one place where the fundamentally existentialist questions about "choice" have retained cultural salience, with implications for political activism. 
problem is, while you're busily unsettling normativity, how not to erect another competing norm that oppresses and marginalizes other people.

Beauvoir had a lot of problems, but this one she avoided: either choice can be lived authentically, she says: it depends. Her ethics are extremely demanding, as I discussed in chapter 1, but they are equal opportunity ethics. The lesbian chapter concludes:

In truth, homosexuality is not a deliberate perversion, any more than it is a fatal curse. It is an attitude chosen in situation, that is to say at the same time motivated, and freely adopted. None of the factors the subject takes on board by this choice - physiological givens, psychological history, social circumstance-is determinative, even though all contribute to explain it. This is for woman one way among others of resolving the problems posed by her condition in general, by her erotic situation in particular. Like all human behaviors, it will lead to masquerades, disequilibrium, failure, lying, or, on the contrary, it will be the source of fruitful experiences, depending on whether it is lived in bad faith, laziness, and inauthenticity, or in lucidity, generosity, and freedom. ${ }^{31}$

“En vérité l'homosexualité n'est pas plus une perversion délibérée qu'une malédiction fatale. C'est une attitude choisie en situation, c'est-à-dire à la fois motivée et librement adoptée. Aucun des facteurs que le sujet assume par ce choix-données physiologiques, histoire psychologique, circonstances sociales—n'est déterminant encore que tous contribuent à l'expliquer. C'est pour la femme une manière parmi d'autres de résoudre les problèmes posés par sa condition en général, par sa situation érotique en particulier. Comme toutes les conduites humaines, elle entraînera comédies, déséquilibre, échec, mensonge ou, au contraire, elle sera source d'expériences fécondes, selon qu'elle sera vécue dans la mauvaise foi, la paresse et l'inauthenticité ou dans la lucidité, la générosité et la liberté" (DS 2:217-18), emphasis in original.

It is hard to know how to translate "assumer"; if one uses "assumes," readers who don't know this is a key existentialist term may assume $[s i c]$ it has its ordinary English meaning. "Takes on board" is at least better than Parshley's "accepts." No wonder I didn't understand this when I read it in English! I have translated "comédies" as "masquerades," which doesn't quite satisfy me, either, since "comédies" for the existentialists includes any occasion on which one "plays a role," even when one is (culpably) unaware of doing so. It's not all that far from Judith Butler's "repeated stylizations of the self," except that Butler thinks this is a good thing (or at least, that it is inevitable), whereas Beauvoir thinks it is a bad thing that free people should (and can) avoid.

Much more might be said about Butler's relationship to Beauvoir: as Lisa Knisely ("Oppression, Narrative Violence, and Vulnerability: The Ambiguous Beauvoirian Legacy of Butler's Ethics") and Diana Coole ("Butler's Phenomenological Existentialism”) have shown in convincing detail, Butler's earliest publications praise Beauvoir for views of sex and gender she would set out in Gender Trouble as her own argument against Beauvoir. H.'s comment seems to have been more acute than I realized at the time. 
That's the last paragraph. But the road by which Beauvoir reaches it is rough.

The chapter opens with the question of "inversion," and here is where the "sandwich" I referred to earlier begins. Her very first statement takes apart the received representation of "the lesbian" as a short-haired woman in a bowler hat and tie whose "virility" results from a hormonal anomaly. Nothing could be further from the truth, she says, than this confusion between the invertie and the virago: lots of lesbians are feminine, and many of the most masculine women are heterosexual. "There is no 'anatomical destiny' which determines their sexuality."32

But why then does she choose the word invertie to name the lesbian? And why does she then launch into a discussion of this very connection between sexuality and soma, drawing on such problematic authorities as Helene Deutsch, Stekel, Ernest Jones, Havelock Ellis, Krafft-Ebing? Why is she even willing to give the time of day to so tainted a concept as "masculine protest," especially since she has handily refuted it in her chapter on childhood? ${ }^{33}$ Has she changed her mind about whether there is, in the static bad sense of "is," such a thing as "feminine" or "masculine," after all?

As I argued in the previous chapter, though, we need to remember to read her use of the psychoanalysts and the other sexologists in volume 2 through the statements about method in volume 1: again, she's making use of their descriptive accounts, particularly on subjects where reliable data are scant, without privileging scientific claims over other sorts of truth claims (made for example by memoir or imaginative literature) and without accepting the underlying determinisms that the scientific or pseudoscientific accounts imply. Psychoanalysts, she says in volume 1, always make the mistake of seeing a "signification" or meaning and taking it for a "reason," and this results in an "ersatz ethics," an ideal of normality. ${ }^{34}$ Here again she is using their case stories, their readings, and even their ways of reading, without accepting the normativity or the moralizing. "The history of the individual is not a fatal procession ... Homosexuality can be, for the woman, a way of fleeing her condition or of taking it on board. The capital error of the psychoanalysts is, through moralizing conformism, never to envision it as anything but an inauthentic attitude." 35 My favorite example of this argument also comes from this chapter:

32 "Aucun 'destin anatomique' ne détermine leur sexualité" (DS 2:192).

33 "[P]rotestation virile" (DS 2:197).

34 DS 1:93.

35 “ $[\mathrm{L}]$ 'histoire de l'individu n'est pas un progrès fatal.... L'homosexualité peut être pour la femme une manière de fuir sa condition ou une manière de l'assumer. Le grand tort des psychanalystes c'est, par conformisme moralisateur, de ne l'envisager jamais que comme une attitude inauthentique" ( $D S$ 2:195). 
The notions of "inferiority complex" and "masculinity complex" remind me of an anecdote Denis de Rougemont tells.... A lady imagined that, when she took a walk in the country, the birds were attacking her. After many months of psychiatric treatment failed to cure her of her obsession, the doctor accompanying her in the clinic garden noticed that the birds were attacking her. ${ }^{36}$

A joke, but one that restores a woman's right to name her own experience, her right to common sense, perhaps even her agency—at least her epistemological agency. Elsewhere Beauvoir says yes, tomboys like to climb trees, but who wouldn't want to climb trees? What requires explanation is not the desire, but its cultural prohibition to half the species.

And in a way, what choice did Beauvoir have? It almost sounds like a party game: try to handle this issue in the twentieth century without using Freud. Try to pick up this plate of Jello without using your hands.

I also see her as using sexological discourse, and the discourse of "inversion," against normativity, against itself. For example, she opposes the idea that every invertie is really a "hidden man" by introducing the stories of a "hermaphrodite" who desired only men and of a "passing woman" who was taken for a homosexual because she followed her male lover into the army. ${ }^{37}$ If our first concern is to prove that gay people are no different from anyone else, we might see the proliferation of strange stories as ultimately pathologizing and sensationalizing the whole topic; but if that's not our first concern, we can see them as cumulatively destabilizing, unhooking gender identity from sexual "preference" and sexual behavior: if so many different things are possible, how could we say that any single simple connection was necessary? "Rien ne suffit à expliquer" why some women are lesbians: nothing suffices to explain it, nothing finally explains it, no one factor can explain it; but some are. Recognizing this is one more way Beauvoir breaks the link between sexuality and procreation.

However, if this was hard for me to see in the 1980 , it must have been even less clear when the book first appeared in the United States. This came home to me when I found the lesbian chapter from The Second Sex included in an

36 "Les notions 'complexe d'infériorité,' 'complexe de masculinité' me font songer à cette anecdote que Denis de Rougemont raconte.... [U]ne dame s'imaginait que, lorsqu'elle se promenait dans la campagne, les oiseaux l'attaquaient; après plusieurs mois d'un traitement psychanalytique qui échoua à la guérir de son obsession, le médecin l'accompagnant dans le jardin de la clinique s'aperçut que les oiseaux l'attaquaient" (DS 2:197).

$37 \quad D S$ 2:193. The first example seems to be based on someone Beauvoir actually knew, who had lived in the same building during the war. She tells the story in La force de l'âge (472) and, somewhat differently, in L'invitée (171-72). 
anthology edited by Hendrik Ruitenbeek, The Problem of Homosexuality in Modern Society, which appeared as a Dutton paperback original in $1963 .{ }^{38}$ Dominated by American psychoanalysts of the type Carol Groneman has brilliantly named "cookbook Freudians" (a pinch of this, a dollop of that, season with prejudice and stir) the book includes essays with titles like "The Flight From Masculinity" and "The Effectiveness of Psychotherapy with Individuals Who Have Severe Homosexual Problems," and it smells strongly of moral panic. Like many popularizations of sexual theory, it also delivers titillation under the legitimating cover of science. ${ }^{39}$ Seeing Beauvoir in this company reminds me how impossible (and wrong) it is to try to extricate the meaning of any work from its discursive surround; while most of the other articles are much worse, it is discouraging to think of readers of the anthology taking at face value Beauvoir's descriptions of "the lesbian" who seeks a narcissistic mirror relationship, "the lesbian" who turns to women because there are no men where she is or because men don't desire her, "the lesbian" who is haunted by a frustrated longing for her mother ${ }^{40}$ — even though, in the context of The Second Sex as a whole, these examples pile up, contradict each other, are declared to be descriptive rather than explanatory, and in the end suggest that the ways of being a lesbian are many, rather than one.

The title of The Problem of Homosexuality in Modern Society is particularly interesting. For whom is homosexuality a problem? For homosexuals, or for the "modern society" that would prefer to exclude them but must learn to manage them? I am reminded of Sartre's statement that the Jewish problem is not a problem for Jews but "our" problem, of Gunnar Myrdal's statement that

38 I am not sure how this happened; probably Beauvoir did not have control over the uses to which her English-language text was put by Knopf.

39 Carole Groneman, Nymphomania: A History. See also Altman, "Everything They Always Wanted You to Know," and Jay Gertzman, Bookleggers and Smuthounds: The Trade in Erotica, 1920-1940.

40 It's especially depressing to remember that pulp paperbacks, of which this is one, were among the few sources lesbians in the 1950s could turn to for information about how to interpret their own feelings. However, gay people have often been very creative at elaborating positive and even political identities from images and ideas acquired in the oddest places.

Not all the essays in Ruitenbeek's book are equally awful; for instance there's a solid social approach by Evelyn Hooker. Ruitenbeek's obituary describes him as "among the first psychoanalysts to advocate equal rights for homosexuals" (New York Times, May 26, 1983), and John D'Emilio discusses his contribution to the movement in Sexual Politics, Sexual Communities: The Making of a Homosexual Minority in the United States, 19401970 (141, 166). According to the Times, he died at fifty-five "as a result of complications from a rare infection, said his sole survivor and adopted son, Richard McConchie." Nineteen eighty-three. Moment of silence. (We won't go back.) 
racism is a white problem. And yet, both alternatives seem troubling: either homosexuality is a pathology (a problems homosexuals have), or there is an "us" whose problem it is and homosexuals who are not "us" become, in Beauvoir's language, the Other. Is she doing the latter thing in her text when she speaks of "the lesbian" as "she"?

In the early 1980s, some American feminist philosophers, among them Ann Ferguson, Claudia Card, and Marilyn Frye, faulted Beauvoir for refusing to take on the possibility of lesbian identity, and for seeming to split off "the lesbian" from "the woman," presumably to the benefit of the latter (conceived as heterosexual). ${ }^{41}$ Ferguson in particular found that Beauvoir's existentialist focus on individual choice had blinded her to the possibility of lesbianism as a political and social collective identity. Frye's argument is characteristically lucid, but all three essays are marred by numerous misreadings, especially of Beauvoir's conception of the body, unfortunate effects of engaging in intense exegesis of brief utterances, as philosophers in the analytic tradition tend to do, rather than locating meaning in the work as a whole. Curiously, all three employ Beauvoir's basic concept, authenticity, in judging her own statements as lacking it. But there is an important kernel of truth here: at the one point in Beauvoir's lesbian chapter where she mentions that certain lesbians like to get together in clubs and groups because they are lesbians - that is, come together around and on behalf of a political identity - they are dismissed as inauthentic, "pointless[ly] grandstanding." ${ }^{2}$ And this occurs just before the concluding paragraph I quoted above.

Does it make sense to object both to what seems to be Beauvoir's refusal (here) of the idea of lesbianism as a group identity, and to what seems to be her assertion of lesbianism as a group identity for "elles," that is, for someone else? The logical contradiction is more apparent than real, though. In the first instance, Ferguson and the others were looking for affirmation of a collective lesbian subjectivity, in the second instance, they were troubled by what struck them as lesbian objectification. ${ }^{43}$ The relation between oppression and identity was, of course, the sixty-four thousand dollar question for gay and lesbian thinkers in the 1980 os, but it was our question, not Beauvoir's, and there may still be something to be said for refusing to answer it.

41 Ann Ferguson, "Lesbian Identity: Beauvoir and History"; Marilyn Frye, "History and Responsibility"; Claudia Card, "Lesbian Attitudes and The Second Sex."

42 "Inutiles fanfaronnades" ( $D S$ 2:217).

43 Similar concerns were raised later by Ursula Tidd, Simone de Beauvoir: Gender and Testimony, 55-7, and Toril Moi, Making of an Intellectual Woman, 199-203. 
It is also misleading to see Beauvoir as focused on individual choice in the way that Sartre (at least the Sartre of Lêtre et le néant, the only Sartre then available to her) indeed unfortunately was. In fact what she talks about when she talks about freedom in that chapter and elsewhere is the freedom to assume one's situation in one or another way. The situation, remember, is the body, plus the social situation, which for her involves givens, données: this was her objection to Sartre's early theory, an objection he'd later take on board. ${ }^{44}$ You have to see that socially speaking some free subjects are freer than others to undertake any kind of analysis of oppression, really—and certainly to become any kind of a materialist, which by 1949 they both were. So to say as Beauvoir does that one can "assume" or take up homosexuality (or heterosexuality) in a number of different ways is not to say that this is a mere matter of individual "preference" like vanilla vs. strawberry. It is in fact not to take a position on that question at all, in the final analysis, which — given what Eve Sedgwick and Didier Eribon say about the potential political dangers of either position in that debate-actually looks somewhat prescient. ${ }^{45}$ It is good also to bear in mind Sedgwick's demonstration in Epistemology of the Closet that one should not expect a person to be consistently essentialist (or social constructionist) about both gender identity and sexual identity: the mixed configuration often appears.

In a way, Beauvoir started the whole problematics of identity with her question - are there women, really? - although I agree with Moi that in the end her answer to that question was, yes. As Beauvoir says about Woman in the discussion of myth: "If she did not exist, men would have invented her. They did invent her. But she also exists."46 So, if no single factor suffices to explain lesbianism, and if lesbian existence may be assumed by individuals in various ways, are there lesbians, really? Her answer by the end seems to be, yes and no; no, but yes. Moi's insight that Beauvoir expected identity to be "a consequence and not a cause of freedom" seems apposite. ${ }^{47}$

But certainly there was nothing here you could build a movement on or around. Or was there? If the objections of Ferguson and Card amount to blaming Beauvoir for not inventing or predicting the identity politics of the $1980 \mathrm{os}$, this no longer looks as bad as it once did. But I also want to question their reading that because she didn't affirm a distinct identity category for lesbians to

\footnotetext{
44 See Sonia Kruks, "Simone de Beauvoir: Teaching Sartre About Freedom."

45 See also Vera Whisman, Queer by Choice.

46 " [S]i elle n'existait pas, les hommes l'auraient inventée.

Ils l'ont inventée. Mais elle existe aussi sans leur invention" (DS 1:303). 
mobilize around, heterosexual normativity forms the basis of The Second Sex. ${ }^{48}$ Again, it all depends on the meaning of the word "is." Perhaps the way samesex desire runs all through the book like a thread, plus the insistence on how difficult and unpleasant the establishment of heterosexual pleasure is, accomplished an anti-homophobic work, or at least made that possible later-in the way that her discussion of frigidity as a perfectly reasonable reaction to married life, and a mode of female resistance, made possible Anne Koedt's "Myth of the Vaginal Orgasm," of which, in fact, the superior rationality of lesbianism is the final argument? ${ }^{49}$ How should we judge a theory: by where it came from? By where it went?

\section{3}

\section{The Time of Writing}

When I first began writing about Beauvoir and lesbians, I thought of defending her on the grounds that 1970 and 1980 os critiques were anachronistic, because the idea of lesbianism or homosexuality as a political identity, a grounding for collective liberation, simply was not available before the Stonewall protest in 1969. But this would be wrong. Christine Bard's wonderful book Les garçonnes: modes et fantasmes des années folles mentions, for example, that in 1924, a prohomosexuality review called Inversions, with both men and women as contributors, appeared in Paris (and was immediately suppressed by the censors). ${ }^{50}$

48 Hazel Barnes, in what is probably the best close analysis of the chapter as a whole, makes a similar argument. Barnes cites Beauvoir-"What requires explanation is not the positive aspect of the invert's choice, but the negative side of the coin: she is not defined by her taste for women, but by the exclusivity of that taste" [Ce qu'il faut expliquer chez l'invertie ce n'est donc pas l'aspect positif de son choix, c'en est la face négative; elle ne se caractérise pas par son goût pour les femmes mais par l'exclusivité de son goût ( $D S$ 2:196)] — and notes: "It is entirely evident that she starts from a position of bisexuality.... The truth is that it is these critics who have fallen into the trap of the binary reasoning they deplore so much, and it is Beauvoir who corresponds to the post-modern position." [De façon tout à fait évidente, elle part de la bisexualité.... La vérité est que ce sont ces critiques qui sont tombés dans le piège du raisonnement binaire qu'ils déplorent tant, et c'est Beauvoir qui correspond aux positionnements post-modernes (Barnes, "La lesbienne," 323-24).] Barnes does not name all the "critics" she means; one she does name is Marie-Jo Bonnet.

49 "Lesbian sexuality could make an excellent case, based upon anatomical data, for the irrelevancy of the male organ.... The recognition of clitoral orgasm as fact would threaten the heterosexual institution" (Koedt, "The Myth of the Vaginal Orgasm," 116).

5o Bard, Les garçonnes, 78. I am deeply indebted to Didier Eribon for pointing me toward this and other crucial resources, as well as for the example of his own inspiring intellectual and political work. 
Beauvoir and Sartre were well aware of the pioneering work of Magnus Hirschfeld's Institute for the Study of Sexuality in Berlin ${ }^{51}$ — "scientific" work (and itself not unproblematic) but clearly directed toward bringing about positive social change in legal and cultural attitudes towards both homosexuals and women, which was why the Nazis burned it. Bard's book documents the storm over Victor Margueritte's controversial best-selling 1920s novel, La garçonne, which caused a moral panic over "the liberated woman" but also became a lifestyle, a fashion sensation, and especially a haircut eagerly adopted by women of all sorts. Semi-pornographic and wildly popular, probably for both good and bad reasons, that novel begins with an attack on the sexual double standard and ends as an argument for companionate marriage, but includes a long excursion into the lesbian "underworld." Bard's discussion shows that there was a significant prewar history to the mutual implication of lesbianism, transvestism as a cultural style, and feminism in France, and that the alliances were not always what one might have expected them to be.

There's a parallel temptation to explain Beauvoir's statement in her introduction, "women ... do not say 'we," by saying that she wrote The Second Sex "before feminism," in a kind of political void. But that, too, would be wrong. There was a feminism in her day, she knew it well—one of its leaders, Cécile Brunschvicg, was married to her graduate school advisor-and she consciously rejected it. (Her full sentence reads, "women-except in certain conferences which remain abstract demonstrations-do not say 'we.") ${ }^{52}$ The French suffrage movement was bourgeois, nationalist, strongly Catholic, and in France as elsewhere many of its early arguments were based in a traditional view of women as moral guardians of the family. ${ }^{53}$ As Bard shows, most feminists joined the culturally conservative attack on Margueritte's novel, and were opposed to the cultural style of the sexually emancipated woman that it both depicted and helped produce. These feminists were not obvious allies for Beauvoir, since the future freedom she projects in The Second Sex is centrally a freedom of sexual self-expression and pleasure for women.

So perhaps it's better to examine Beauvoir's conscious rejection of lesbian collective identity by specifying historically which forms of this were available and visible to her. What was she responding to? Should we see her analysis (some have) as cowardly, as yet one more example of Marcel Proust's famous

\footnotetext{
$51 \quad F A 153$.

52 "Les femmes—sauf en certains congrès qui restent des manifestations abstraites—ne disent pas 'nous"' (DS 1:19). She's drawing a contrast to Blacks, especially "the Blacks of Haiti," and proletarians.

See Sylvie Chaperon, Les années Beauvoir, 1945-1970.
} 
insight that it would be no good rebuilding Sodom, because all the actual sodomites would immediately flee, crying, "I'm not one of those"? ${ }^{44}$ The effects of oppression should never be discounted. ${ }^{55}$ But there may be more to see.

Didier Eribon has drawn my attention to some of the ways homophobic remarks were used after the war, by Sartre and others, as part of the épuration (purge) whereby the literary establishment, with Sartre the young Turk now firmly at its center, cleansed itself of those writers who had collaborated with the Nazis. For example, in "Qu'est-ce qu'un collaborateur?" (What is A Collaborator?), Sartre wrote that because collaboration was feminine, it was not surprising that so many of the collaborators were homosexual. ${ }^{56}$ Eribon commented, "the assertion is unbearable, but it is also true." ${ }^{77}$ Many of the writers and artists who collaborated were, in fact, homosexuals, members of what Eribon called "our tradition"-Marcel Jouhandeau, Jean Cocteau, Colette (who seems to have contributed to a fulsome festschrift for the traitorous Vichy leader, Maréchal Pétain) — and there was a strong, and repulsive, homoerotic element to the embrace of the fascist "blood consciousness," under the sign of "revolutionary" (woman-hating) masculinity, by such targets of the épuration as Robert Brasillach and Maurice Bardèche. Of course, as Eribon went on to say, many members of the Résistance were also homosexual, and it is important not to oversimplify what led various people to do, or not do, various things during the war: ${ }^{58}$ his underlying argument is that being homosexual, even being a pro-homosexual homosexual, was (and is) no guarantee that a given writer (or human being) would take progressive positions on other issues; it did not (and does not) insulate anyone from the worst political mistakes and crimes. (Eribon's political conclusion is that solidarity must be demonstrated

54 See Eve Kosofsky Sedgwick, "Proust and the Spectacle of the Closet," and Eribon, Réflexions sur la question gay.

55 "September 9 [1939].... I go to the Dôme with Olga. There are two little lesbians next to us, and one gets into a thing with the waiter: 'I don't talk to waiters,' she says; and the moustached waiter, easy-going yet threatening: 'But waiters have ears to hear, and what they hear they can repeat, and the dungeon of Vincennes is nearby." [9 septembre (1939).... Je vais au Dôme avec Olga. Il y a deux petites lesbiennes à côté de nous, et l'une s'engueule avec le garçon: "Je ne parle pas avec les garçons," dit-elle; et le garçon, moustachu, bonasse et menaçant: "Mais les garçons ont des oreilles pour entendre, et ils peuvent le répéter et le donjon de Vincennes n'est pas loin" (FA 443).] "Garçon" is also the word for "boy," so there's a double entendre: "I don't talk to boys."

56 Sartre, "Qu'est-ce qu'un collaborateur?"

57 Eribon, "Fascists, Anti-Semitism, and Homosexuality in France since the 1930s."

$5^{8}$ See Alice Kaplan, Reproductions of Banality: Fascism, Literature, and French Intellectual Life and The Collaborator: The Trial and Execution of Robert Brassilach; Erin Carlston, Thinking Fascism; Gisèle Sapiro, La guerre des écrivains; Klaus Theweleit, Male Fantasies. 
and can never be presumed. $)^{59}$ My own point here is simply that if Beauvoir looked around her for examples of homosexual clubs or "interest groups," some of what she saw wasn't very pretty.

Indeed, going back to prewar Germany, the socialist pro-inversion model of Hirschfeld's Institute could be contrasted with the repressive, anti-Semitic, and militantly anti-effeminate homosexuality of the Ernst Röhm circle and the Wandervogel groups. At the same panel where Eribon spoke (at a Chicago conference on "The Future of the Queer Past"), Todd Shepard showed that, a bit later, French critics of torture in Algeria would be attacked by French nationalists as pederasts; meanwhile those leftist activists themselves described the torturers as homosexual. ${ }^{60}$ In short, we need to recognize both homosexual identity and homophobia as generally available languages that were not marked as either Left or Right, as either pro- or anti-woman. Again, the Foucault touchstone seems apt: "There is not, on the one side, a discourse of power, and opposite it another discourse that runs counter to it."61

I do not mean to excuse Sartre's remark, merely to contextualize it. Note that (unlike Beauvoir) he seems committed here to a rather simplistic version of the "inversion" model, and willing to use the term "feminine" as though it had a stable and permanent meaning. In fact the picture of homosexuality in his work overall is murky. Sometimes he presents a homosexual as a striking example of a person caught in an attitude of "bad faith": Daniel in Les chemins de la liberté (The Roads to Freedom) is a clear example of someone who is unable or unwilling to assume his freedom in any authentic way, and he serves as a foil to the heterosexual male protagonist, who can't quite handle his freedom,

59 This seems truer, and even more unbearable, than when he said it in 200o. Xenophobic mobilization against Islamic immigrants in the Netherlands, the most sexually "progressive" country in the European Union, partly on that basis; charges of racism against the Human Rights Campaign ... Milo Yiannopolous...

6o Questions of homosexuality in France were deeply involved with national identity and pride, with military and reproductive vigor. One may compare the McCarthyite charge that homosexuality, like Communism, was "un-American," and note the deep connections between anti-Semitism and homophobia in both cases. This helps contextualize, for example, why there is so much about the Dreyfus affair in Proust's Sodome et Gomorrhe, and why Gide's L'immoraliste opens with a fictional letter from a not unfriendly government official, who asks, "how can a man like Michel serve the state?" (Limmoraliste, 3; emphasis added).

61 Foucault, History of Sexuality, 101. He continues: "Discourses are tactical elements or blocks operating in the field of force relations; there can exist different and contradictory discourses within the same strategy; they can, on the contrary, circulate without changing their form from one strategy to another, opposing strategy. We must not expect the discourses on sex to tell us, above all, what strategy they derive from, or what moral divisions they accompany, or what ideology they represent; rather, we must question them...." 
either, but is at least making a lucid effort. The lesbian in Huis clos (No Exit), who may be partly based on Beauvoir, is morally sophisticated without being sympathetic. In "L'enfance d'un chef" (The Childhood of a Leader) there's more than enough homosexual bad faith to go around, but it's hard to tell against whom the satire is directed, exactly. But Sartre's fullest treatment of the issue, in his book about Genet, may show (one form of) male homosexuality as a fully authentic choice. It interests me that Sartre wrote about Genet after reading The Second Sex, and in fact he even cites some of Beauvoir's descriptions of "la femme" - a thing people often suppose he never did. ${ }^{62}$ On the other hand, he is working quite firmly within an "inversion" model (as if Genet and his male homosexual characters were "really" women, and thus Beauvoir's thoughts about femininity would be helpful in understanding them). Might he, too, perhaps with her assistance, have come to see homosexuality (like heterosexuality) as something people might "assume" either authentically, or otherwise? He does not seem to have thought so in 1945, when his introductory manifesto for Les Temps Modernes stated (as part of an attack on Proust), "we refuse to believe that a homosexual's love has the same character as a heterosexual's." ${ }^{63}$ Presumably he saw this differently by the 196os, when he would take a public stand in favor of Gay Liberation, and against state censorship of their publications. Whether one chooses to see his view as self-contradictory, or as evolving in a progressive direction, one thing seems clear for Sartre and also, I think, for Beauvoir: the major sources for their views of homosexuality were not psychoanalytic or sexological, but literary.

The unsettling, destabilizing move that Beauvoir accomplished for so many readers was mainly accomplished for her, I think, by her early reading of André Gide. In Mémoires d'une jeune fille rangée she records her encounter at the age of fifteen with the literature of inquiétude (restlessness), to which she was introduced by her cousin Jacques, and her eager embrace of Gide's values, "sincerity" and "immoralism." She quotes particularly the famous sentence from his 1897 Les nourritures terrestres (The Fruits of the Earth): "Family, I hate you!

62 Sartre, Saint Genet, Actor and Martyr, 37, 57, 291. For fuller discussion of how Beauvoir's conception of the Other influenced Sartre's book on Genet, see Simons, Beauvoir and The Second Sex: Feminism, Race, and the Origins of Existentialism, 46.

63 "Nous refusons de croire que l'amour d'un inverti présente les mêmes caractères que celui d'un hétérosexuel" (Sartre, "Présentation," 12). 
Shut-in homes, bolted doors."64 "We were on the same side," she notes-not least, as she saw in humorous hindsight, because Gide and other violently antibourgeois writers were themselves disoriented children of the bourgeoisie, and because their revolt, interior and poetic rather than social or political, could enable one to take deep intellectual pride in an adolescent spat with one's mother. Still, his influence endured. As a young teacher, she tried to pass on Jacques's awakening gift to her by teaching and discussing Gide's views with her students, with mixed success: parental complaints resulted in a series of unpleasant incidents with the authorities, which perhaps prepared the way for her dismissal from the teaching corps for "détournement de mineur." By this time, she could have shared with them the overt, if somewhat bizarre, sexual theory Gide offered in Corydon (1924) and the franker insights about his own homosexual experiences, which he'd sketched as fiction in L'immoraliste (1901), then openly presented in the autobiographical Si le grain ne meurt (1926). One wonders what she told them. At the most intense period of triangular sexual activity with Sartre and various of her students and younger friends, she was avidly reading Gide's journals ... and sending them on to Sartre and to their young friend Jacques Bost in the army, as soon as she finished them. ${ }^{65}$

It's hard now to see Gide's work as in any way sexually progressive: the early work is timid, diffuse, coy, shot through with religious agony and moralizing; Corydon's insistence on a Greek pedagogical model of masculine, even military (and non-sexual) pédérastie rests on a deep and absolutely explicit misogyny; L'immoraliste and the most autobiographical narratives eroticize colonial "natives" and lower-class boys generally in a thoroughly racist and insufferably aristocratic way, and ... well, frankly, one can't help feeling sorry for his wife, imprisoned all the while in celibate respectability. To understand why Beauvoir found Gide's writings revolutionary and even empowering, one needs to realize how profoundly Catholic and bourgeois and nationalist and generally stifling the "foyers clos" of her milieu were; that in her mother's house one could transgress sexually just by being alone in a room with a man, the best kind of marriage was an arranged marriage, etc. Must one see in Beauvoir's appropriation of Gide another example of what Le Dœuff has called Beauvoir's "genius for the inappropriate"? 66 Perhaps it is simply the operation of a common mechanism of readerly identification: identification with/in narrative,

64 "Famille, je vous hais! foyers clos, portes refermées" (MJFR 268). Ménalque, the character who says this, is often seen as a version of Oscar Wilde.

65 FA 111-12. Si le grain ne meurt may have been one model (among others) for Mémoires d'une jeune fille rangée, where Beauvoir seems similarly concerned to trace the steps of her sexual coming-of-age in a matter-of-fact, straightforward tone. 
unlike adherence to a philosophical or political position, is rarely single or total, sole or whole, and is not meant to be.

In any case, Gide's explicit taking up of the cudgels "pour l'homosexualité"for which despite his unparalleled cultural capital he was duly vilified-did not provide any space for lesbian identity. His was hardly a call to arms any woman could reasonably heed. But the insistence that homosexual men were not effeminate or "inverted" — au contraire! en garde! — made a point that may have been theoretically useful to Beauvoir in a different way. In the lesbian chapter, she remarks in passing that

[e]ven man does not desire woman exclusively; the fact that the organism of the male homosexual may be perfectly manly implies that the manliness of a woman does not necessarily commit her to homosexuality. ${ }^{67}$

And the observation, or the unsettling move, may touch the book's argument as a whole as well: because once the question of femininity has been raised with respect to men, that is, to those who are biologically male, the question of what femininity can mean for anyone, including women, has been raised. The word "femininity" has acquired its implicit inverted commas, and a return to naïve essentialism about gender is (or should be) impossible. ${ }^{68}$

The history of homosexuality in French literature has often been written in the light of Proust's advice to Gide- "you can tell everything, as long as you never say 'I'" (advice Gide ignored). ${ }^{69}$ As a result of this comment, of the presumed (though somewhat unusual) heterosexuality of the narrator in $\grave{A}$ la recherche du temps perdu, and of the fact that some of his portraits of what he calls invertis are less than flattering, Proust is often seen as the loser in this exchange, as an apologist for the closet or even a self-hating homosexual. Like Beauvoir, he oscillates between diverse and complicated and self-contradictory

67 "L'homme même ne désire pas exclusivement la femme; le fait que l'organisme de l'homosexuel mâle peut être parfaitement viril implique que la virilité d'une femme ne la voue pas nécessairement à l'homosexualité" (DS 2:193).

68 The issue of whether a homosexual man really "is" a woman might look different, too, after Beauvoir's critique (what is a woman, are there women, really) places those inverted commas around "is," and de-biologizes the question of "femininity." I would like to think this was a legacy from second-wave feminism to the gay (and gay and lesbian) movements of the 1970 and 1980 s.

69 "[V]ous pouvez tout raconter, mais à condition de ne jamais dire, Je" (Gide, journal entry for May 14, 1921, quoted in Michael Lucey, Never Say I: Sexuality and the First Person in Colette, Gide, and Proust, 1). A younger Gide had already received (and ignored) the same advice from Oscar Wilde himself: "promise me, never write 'I' anymore.... In art, you see, there is no first person" (Alan Sheridan, André Gide: A Life in the Present, 148). 
portraits of individuals, their behavior, its meaning, etc., and blanket theoretical statements about l'inverti, the homosexual. And like her he has been blamed for conforming to his own joke about the sodomites who flee Sodom pour ne pas avoir l'air d'en être, so as not to be taken for "one of those."70

I think this is unfair. It's possible to argue that in $A$ la recherche as a whole, the question of inversion, after a million tortured explanations, twists and turns and exceptions, falls apart of its own weight or, if you like, deconstructs itself. By the very end of the work it has been said of nearly every character that he or she "en est une" (is one of those), at least sometimes; as Eve Sedgwick points out, the question of sexual identification becomes progressively less coherent and more interesting. ${ }^{71}$ Finally the question about "en être" - who is one of those? - may be answered as Beauvoir answered the determinists: it all depends what you mean by "être." The key element for Proust is, of course, time, which produces "les intermittences du cœur" and allows for change and contingency. Perhaps what we're seeing here is a love that would prefer not to speak its name, because all the available names feel wrong. In any case, Proust was another writer Beauvoir read and reread throughout her life; his thought was formative to how both she and Sartre, and indeed the French generally, thought through the question of homosexuality (and the related question of Jewishness). ${ }^{72}$

Beauvoir's debt to Proust was profound and productive. But the helpfulness of male models to lesbian writers tends to be ambiguous. In Proust, men who desire men and women who desire women occupy very different epistemological positions. The questions he poses about homosexual men are questions about the formation of subjectivity: who or what is this guy, what does he want and why does he want what he wants, how did he get that way, etc., with the old "who or what am I?" lurking in the street outside or peeping over the transom. But the lesbian question is always "does she or doesn't she?" and it is posed by an amorous or voyeuristic male subject to whom the woman's desire

$70 \quad$ Marcel Proust, Sodome et Gomorrhe, 615-32.

71 Sedgwick, "Proust and the Spectacle of the Closet." À la recherche du temps perdu is another very long book which will look quite different depending on whether one reads and absorbs the whole thing, or takes the part for the whole. I'd argue, for example, that Charlus is not "the homosexual" in any reified way; but one must live with him well into the final volume, and his old age, to grasp that he is, in fact, Charlus, and not "the" anything. (He is not even "a" Charlus; he is himself.)

72 Discourses about homosexuality and about Jews are inextricably related throughout Europe at this period, in ways I haven't space to discuss. See Carlston, Thinking Fascism. See also Altman, "A Book of Repulsive Jews? Rereading Nightwood." 
remains opaque, and for whom its ambiguity is a source of anxiety. ${ }^{73}$ This anxious gaze is objectifying or, more accurately, is about objectification, because Proust's point is precisely that objectification doesn't work. No one but Odette will ever know what Odette is thinking or feeling, or what she wants, even at the moment of the act of physical "possession" - "in which, in any case, one possesses nothing," as Proust says-a very Beauvoirian point. ${ }^{74}$ We're surprisingly close, here, to Sartre's and Beauvoir's account of "the Look," the moment where one suddenly remembers that one is not the only subject in the world, and that the other person may have a different idea about what is going on. ${ }^{75}$ And despite the ineffable silence of women in Proust's text, I would not be quick to say whether Swann or Odette, "Marcel" or Albertine, finally has the upper hand.

But if Beauvoir sought literary models for full-fledged lesbian subjectivity, Proust could be little more help than Gide. She turned instead to the tradition of the girl's school crush romance story (or, to put it more elegantly, the lesbian Bildungsroman): Mädchen in Uniform, Dusty Answer ... turned to it in The Second Sex, in her novels, and perhaps even in her own life. ${ }^{76}$

\section{$5 \quad$ Lesbian Reading}

She would not say of any one in the world now that they were this or were that ...

VIRGINIA WOOLF, Mrs. Dalloway ${ }^{77}$

73 Sedgwick also observes that the language of "inversion" is never applied to the lesbians in the text (234); it is not Albertine's gender identity that is in question, but the things she (maybe) does, the features of her life that escape the narrator's gaze.

74 “[O]ù d'ailleurs l'on ne possède rien" (Proust, Du côté de chez Swann, 275). Compare Beauvoir's description (discussed in chapter 1 above) of eroticism as a revolt of the instant against the flow of time, and thus unsocializable in any systematic way.

75 Sartre sees this mainly as the opening of hostilities between competing subjectivities, at best a source of nausea, where for Proust it is the beginning of all desire.... In Linvitée, Beauvoir seems to do both:Xavière is an opaque and therefore fascinating object of desire for both Françoise and Pierre, but as the source of a competing view of Françoise to Françoise's own view of herself she is so threatening that she must be killed at the end of the novel.

$7^{6}$ The schoolgirl romance was largely an English vein, but it would be mined by Beauvoir's protégée and disappointed admirer, Violette Leduc, in such works as La bâtarde and Thérèse et Isabelle and, very differently, by Monique Wittig in her marvelous first novel, L'Opoponax.

Woolf, Mrs. Dalloway, 8. 
But lesbian erotics are only partially about conscious victories and romantic sunsets. They are also about conscious and unconscious struggle, circulations of power, failure of nerve, and fear of loss, always in the context of a hostile public.

CARolyn ALLEN, Following Djuna ${ }^{78}$

The "lesbian question" has been, and is, a literary question, as Julie Abraham shows at the beginning of Are Girls Necessary?.

In Anglo-American culture, fiction has been a primary arena for the representation of sexuality and gender and the construction of identities. First cousin to the case history, and more accessible than scientific texts, novels remained over the first half of the twentieth century easier to produce and harder to censor than theater or film. So, for a combination of formal, cultural, and material reasons, the novel has been the genre in which representations of lesbianism have been recognized.

As Abraham argues, quite a bit of twentieth-century writing by and about lesbians goes on outside "lesbian novels" about happy or unhappy couples, "coming out," and so on, and it takes longer to recognize or even notice what is lesbian about the work of, say, Willa Cather or Gertrude Stein. "Nonetheless it is surprising ... how much lesbian writing contains aspects of the subjects and formula of the lesbian novel. ${ }^{\text {" }} 9$

Abraham's work mainly references British and American fiction, and so, to a surprising extent, does Beauvoir's. Or perhaps what is surprising is to what extent the lesbian literary tradition was an Anglo-American phenomenon. ${ }^{80}$ Indeed, the women's literary tradition was. ${ }^{81}$ Beauvoir's autobiographies record a fiction-dependent process of self-formation and Bildung strikingly similar to the stories Rachel Brownstein and Nancy Miller have told about middle-class girls reading under the bedcovers, learning to write and live their own stories. ${ }^{82}$ After all my careful attempts at historicity and distance, it is startling to realize that Beauvoir read what I read: that she wept over Little Women, then threw it across the room when she learned that Laurie married the insipid, pretty Amy,

78 Carolyn Allen, Following Djuna: Women Lovers and the Erotics of Loss, 23.

79 Julie L. Abraham, Are Girls Necessary?: Lesbian Writing and Modern Histories, xiii.

8o Even Renée Vivien and Natalie Barney, who lived in Paris and wrote in French, were Americans. The only exception, if she even counts, is Colette.

81 See Susan Suleiman, Subversive Intent: Gender, Politics, and the Avant-garde, 30.

82 See Nancy K. Miller, "Emphasis Added: Plots and Plausibilities in Women's Fiction," and Rachel Brownstein, Becoming a Heroine. 
and not the clever and bookish "Joe [ sic]";83 that she took to heart the sorrowful story of Maggie Tulliver in The Mill on the Floss, and vowed to do better by becoming, not Maggie, not Lucy, but George Eliot; ${ }^{84}$ that she read all of Woolf's novels and essays as they appeared, even made her way through Dorothy Richardson's Pilgrimage. ${ }^{85}$ As a girl who sought models and possibilities in her reading, rather than her milieu, which was limiting and distressing, she had taught herself (by the time she met Sartre) the first half of the "women in literature" survey as it would appear in the United States around 1975.

Many of the texts named in her autobiography find their way into The Second Sex, too, supplemented by examples and arguments drawn from Woolf's $A$ Room of One's Own. But how can fiction be source material for philosophy? What kind of book is this, anyway? Genre matters because it determines what kinds of truth claims are being made, and what will constitute acceptable evidence for those claims. But genre also matters because it determines how readers are being invited to participate in the work of constructing a text. Who is, and who isn't invited? What implicit contracts between writer and reader are in play? What relationship, what community, is being constructed? (Or imagined, through an intuition of future community among a set of solitary readers, each isolated, and yet all passionately engaged.)

I am sympathetic to the insistence of Christine Delphy, and numerous feminist writers internationally, that "Simone de Beauvoir, c'était un philosophe," which I take to mean, pay attention to what she actually said, take its propositional content, so to speak, seriously, and argue for or against it in a grown-up way; master your transferences, be a reader and not just a fan. Beauvoir's exclusion from the philosophical canon as it is read and taught resulted from pure misogyny; disagreeing with that exclusion is a key move in recognizing her importance as a thinker, period. Agreed. Yet philosophical accounts can tend to smooth out the lumpy, digressive, baggy texture of Beauvoir's writing, and leave out the parts of The Second Sex that, whether I love them or hate them, seem most meaningful to me: the stories about women, told in their own words. ${ }^{86}$

\footnotetext{
$83 \quad$ MJFR $122-24$ and $145-46$.

84 MJFR 194-95.

85 "Dorothy Richardson's interminable novel, which over the course of ten or twelve volumes succeeds at telling absolutely nothing." [[L]'interminable roman de Dorothy Richardson qui réussit pendant dix ou douze volumes à ne raconter strictement rien (FA 63).]

86 As I hope I showed in chapter 1, what we hear in the extended sexological and psychoanalytic examples is often not the voice of the "expert" but the suffering woman; in the same way, we often seem to be hearing from the heroine of a novel, rather than the novel's male author.
} 
The Second Sex is not a lesbian novel. But if it were a lesbian novel, what lesbian novel would it be?

Not Radclyffe Hall's The Well of Loneliness, which Abraham and most other commentators see as the formative template for twentieth-century lesbian literature. In a footnote to the last paragraph of the lesbian chapter, Beauvoir says, "The Well of Loneliness presents a heroine marked by a psychopathological fate. But the documentary value of this novel is very thin, despite the reputation it has found." ${ }^{87}$ What did she dislike, one wonders: Hall's ersatz ethics? the God-talk? The tortured final plea for tolerance toward homosexuals as a group? The stereotypical division Hall draws between "real" (mannish) lesbians and the other, temporary, feminine kind, a distinction that other sorts of "documentary" evidence, cited in Beauvoir's chapter, falsifies? Hall's excruciatingly bad writing? Or ... maybe it was the maudlin unhappy ending, the selfsacrifice of the guilt-tripped heroine, and her seemingly inevitable defeat and misery?

A closer model may have been Rosamond Lehmann's Dusty Answer, which Beauvoir and Zaza read together, and which Beauvoir tells us she tried to imitate in her own first unsatisfactory attempts to write. ${ }^{88}$ She draws on it, and on another Lehmann novel, Invitation to the Waltz, repeatedly in the parts of The Second Sex that deal with the young woman's development, the Bildungsroman parts if you will. Only Alain-Fournier's Le Grand Meaulnes seems to have made a comparable impression on her young projections of how her life, and her writing, might turn out.

Lehmann herself was a 1920s English writer to the bone, linked with other post-World War I feminists (Vera Brittain, Winifred Holtby, Storm Jameson, Rebecca West) who have been relegated, with some justice and some injustice, to the B-list as more of sociological than literary interest. Her books, to borrow a phrase from A Room of One's Own, lay about in second hand shops like fallen pockmarked apples, until the day they were found and resurrected as Virago Modern Classics. ${ }^{89}$ There is no such thing as "women's writing," but if there were, these would be it. They sit on the border between being "good bad novels" and "bad good novels," by which I mean that they make tremendous use of sentimental longings, on the part of characters and readers-both are tremendous tearjerkers-even as they sketch an ironic awareness of the limitations

$87 \quad$ "Le puits de solitude présente une héroïne marquée par une fatalité psychophysiologique. Mais la valeur documentaire de ce roman est fort mince en dépit de la réputation qu'il a connue" $\left(D S_{2: 217} \mathrm{~N}\right)$.

88 Most of these early attempts remained unfinished. See Altman, "Necessity but [unintelligible]."

89 Lehmann is to Woolf as Howells is to James. 
posed for a young woman by her inscription and self-inscription in romance plots. Imagine D. H. Lawrence's Ursula, or Miriam, transplanted into a Jane Austen novel, and you will have a fair sense of Invitation to the Waltz's Olivia, Dusty Answer's Judith. (Naked swimming and rapture over gardens feature heavily.) Lehmann appeals to the instincts of romance-reading even while she seems to sow the seeds for seeing beyond them. ${ }^{90}$ What she captures best is the intensity of sexual feeling and power of sexual fantasy in the life of a creative young girl; and also the profound humiliations into which such feelings can lead her, given that other people (especially young men) may have different ideas, or just limited imaginations. The attraction of Dusty Answer may partly have been that it shows sexuality as confused, diffused, and multiple. Judith's love for Jennifer is central, sensual, lyrical, and her grief and confusion when Jennifer leaves her (for an older woman more clearly marked in the text as lesbian) cut very deep. But Judith is simultaneously in love with, and attracted to, a variety of other people, including a man who keeps trying to warn her that he is homosexual.

Dusty Answer has usually been discussed in terms of its contribution to the canon of "lesbian images," and as such it has been judged wanting, in terms that strikingly recall the criticisms of Beauvoir I described earlier. English critic Gabrielle Griffin compares it to Clemence Dane's (monstrous) Regiment of Women, complaining that Jennifer and Judy's relationship is "pre-sexual" and familial, while Jennifer's relationship to the more masculine Geraldine Manners is "purposeless," "deracinated," "promiscuous" and provides no viable alternative. ${ }^{91}$ One thing that might be said of these criticisms is that they keep us from reading and enjoying the book on its own terms; another is that they develop an ersatz ethics no less chilling than the heterosexual plotting Griffin presumably means to oppose. (What conceivable lesbian image, or reality, would be acceptable?)

What did Beauvoir look for, and find, in Dusty Answer? Arguments of the "Emily must have felt" sort often feel tricksy. But having compared Lehmann's novel with Beauvoir's autobiographical writing about her youth, and with her youthful diaries, I want to speculate that she didn't pore over it in a hungry search for lesbian representation, for information about her own same-sex desires, for cultural legitimation that would bless her union with her friend Zaza

9o See Suzanne Clark, Sentimental Modernism, and Janice Radway, Reading the Romance, for a less unsympathetic view than mine of the romance genre.

91 Griffin, Heavenly Love? Lesbian Images in Twentieth-Century Women's Writing. Despite its date, 1993, Griffin's book sits firmly within a strong lesbian-feminist paradigm, and opens with a polemic against queer theory. 
and empower her to give up on Jacques. Rather, she sought and found a young woman full of life, full of passionate feeling for people of both sexes, and also of a longing to be herself for herself first ... and capable too of study and intellectual detachment, but unwilling to give up on love.

Does this have to be inauthentic? Isn't it how it just, uh, is, sometimes? Or, in the dignified phrase Beauvoir chose sometimes when she wished to introduce her own life into that dignified philosophical tome, The Second Sex, "I myself know some women who..."

\section{Lesbians and L'invitée}

But of course The Second Sex is not a lesbian novel, or any other kind of novel. The closest thing to a lesbian novel Beauvoir actually wrote was L'invitée. ${ }^{92}$

L'invitée is a lesbian novel only in the way that To the Lighthouse and Mrs. Dalloway are, in the same way (but much more strongly) that according to Barbara Smith Sula is one. ${ }^{93}$ They don't signal themselves as such, aren't The Well of Loneliness or Riverfinger Woman; they do not say "we." But there are a few passages that, once you've understood them, radiate meaning subtly throughout the whole text. ${ }^{94}$ And you say to yourself, or your students, well what did you think it was about, silly? Once pointed out, the emotional current is irreversibly evident. But such works are totally unconcerned about "lesbian identity," about drawing a line of demarcation between heterosexuality and homosexuality.

L'invitée includes a number of scenes between Françoise and Xavière that are both emotional and erotic, including a number of scenes where the two of them together appreciatively watch other women..$^{95}$ This may help us make sense of the intensity of Françoise's desire to bring Xavière to Paris, and of her sadness when Pierre decides to make seducing Xavière one of his projects, in a sense cutting Françoise out of her share of Xavière's affection: she is jealous of both of them. Eroticism between women, while never named, is diffused and

92 Julie Abraham makes a distinction between "lesbian novels" and "lesbian writing" which I am not following here; my usage of the term "novel" is looser.

93 Barbara Smith, "Toward a Black Feminist Criticism."

94 Rich's idea of "lesbian continuum," Audre Lorde's similarly diffuse and inclusive notion of "the erotic," might be relevant here.

95 Xavière, who is described as both opaque (in the manner of Proust's êtres de fuite) and perverse, has a fine selection of pinups on the wall of her room. Some, though not all, of the women they watch together are women of color. I'll return to this issue in chapter four below. 
unsettling throughout ... in the same way that the deep bonds between men are diffused, unsettling, troublants throughout Le Grand Meaulnes and the early work of Gide. The "pedagogical model" of the relationship also seems influenced by Gide's life and work, as well as by some of the schoolgirl lesbian romances I discussed earlier.

As much as I have learned from Toril Moi's work on Beauvoir, I find myself dissenting from her Freudian and somewhat Kristevan reading of Linvitée. To me, L'invitée is not about separating from the symbiotic mother. ${ }^{96}$ It is, among many other things, about not quite having the courage to bring another woman out, to be a younger woman's first and real lover; and envying the men for whom heterosexual seduction is an obvious, and culturally syntonic, move. Perhaps an insight into the ethical limitations of the pedagogical model itself-an awareness she began developing in the manuscript that became Quand prime le spirituel, and that took its baldest form in her much later statement to Nelson Algren, "I happened to behave very badly" - is at least on the horizon as well. What's interesting is that because lesbian desire is never named, it need never be named as a problem, a crime, a disease, or any of a number of other distressing options that were certainly culturally available to Beauvoir. The question of how the characters' behavior might relate to conventional morality (whether bourgeois or Kantian) is simply irrelevant. Possibly an advantage.

This does not really make L'invitée a lesbian novel. But it is not exactly a heterosexual novel either, because the heterosexuality it foregrounds is an attempt to, in Woolf's phrase, "live differently."97 However problematic this turns out to be (it does lead to murder) the attempt is never abandoned. For this reason Toril Moi's question, why Françoise doesn't just do the obvious thing and ask Pierre not to sleep with Xavière, seems misguided. To do that, to enact the same sort of possessive jealousy as an ordinary bourgeois wife, would be to vitiate not just the basis for that couple's original "pact," but the whole idea or original choice around which Françoise is constructing her own new form of subjectivity in relationship. The final line, "[e]lle s'était choisie" (she had chosen herself) doesn't mean, or doesn't only mean, that she killed Xavière so she could keep Pierre for herself- that would reaffirm the heterosexual plot; rather I think it means, she chose to keep her different story going, even though there was no existing paradigm within which her story could be said to "make sense." Perhaps precisely for that reason. Just as in the lesbian chapter of The Second Sex, ethical questions about the authenticity or inauthenticity of desire

96 Moi, Making of an Intellectual Woman, 118-23.

97 Woolf, The Years, 286, 309. 
are foregrounded; but here, ideas about homosexual versus heterosexual desire, about lesbian "identity," do not speak to these questions: so they are silent..$^{98}$

\section{$7 \quad$ Last Thoughts}

La théorie, c'est bon, mais ça n'empêche pas d'exister. Charcot quoted by Freud ${ }^{99}$

Sexual theory has been traditionally used to say, "People have been forced to be this thing; people could be that thing." And you're left in the middle going, "Well, I am here, and I don't know how to get there." It hasn't been able to talk realistically about where people are sexually.

AMBER HOLLIBAUGH ${ }^{100}$

As I said above, The Second Sex is of course not a lesbian novel, or any other kind of novel. But I do hope that this juxtaposition at least helps us wonder whether it can finally be judged to be monologic. So many competing voices, saying so many different things, at such length, so many instances of "on the other hand," are not digressions from her point, they are the point. This has profound implications for how we read it, both for the experience of (sitting there and) reading it, and for the final act of deciding "what she means" and passing political judgment. A certain statement, presented as a generalized account of how things always are for everyone, may offend me terribly; if it is offered, instead, as a story among others, I may swallow it, may even remember a similar story that once happened to me, may now read my own story differently. If identification with the text, like identification in reading a novel, need not be sole or whole or involve identity, perhaps the resulting text will speak to many different readers and seem to be saying many different things? (As this one, remember, did.)

Perhaps one might call the lesbian chapter a piece of literary criticism (among other things). An attempt to put together, to cut together (in the sense of montage) a picture of "lesbian existence" from the documents that were to hand, judging some more effective than others but leaving in a lot of rough

$98 \quad$ A very compelling 2010 article by Michael Lucey, "Simone de Beauvoir and Sexuality in the Third Person," reaches a similar conclusion by a different route.

99 Roazen, Freud and His Followers, 72.

100 Amber Hollibaugh and Cherrie Moraga, "What We're Rolling Around in Bed With," 72. 
edges. Because she did not trust her own fragmentary experience, or her understanding of it? Or, because she wanted it to be better than it had been for her?

Or because she did not in the final analysis wish to speak for others?

Who knows? I am not however interested in fleeing Griffin's ersatz ethics in the other direction, and suggesting that every indication of lesbian existence, however slight or problematic, constitutes a "queer touch" that renders the text and the author deliciously subversive. Foucault's insight cuts both ways, cuts many more ways than two.

What then is the theoretical payoff, for example for some future conversation I might have with H., or with my feminist students who wonder quite reasonably what any of this has to offer them? If what is useful and exciting is always the first awareness, the first unsettling move, the first undermining of heterosexist "common sense," the first uncoupling of sex from gender and of sex-as-it-has-been from sex as it might be ... well, this can be accomplished by a number of "theorists" in a number of ways. What Gide did for Beauvoir, Beauvoir did for Judith Butler, and Butler did for H.; it was probably Foucault who did it for me. A true and important thing will be thought more than once and by more than one very smart person. This does not particularly help us assess the adequacy or inadequacy of the various theories we have in front of us. But maybe that's the wrong game.

My original claim was a modest one: simply that it is interesting and worthwhile to read Beauvoir, and to read her in this way, in time. This is the sort of claim literary critics like myself do tend to make, though we sometimes dress them up in fancier language. It might be tempting to make a stronger claim: that the readings of Ann Ferguson et al. were "gay" or "lesbian" readings, which accounted for their flaws, and that my own reading was "queer" and therefore better. (As some are now saying that The Well of Loneliness is not, as was thought, a bad and somewhat cowardly novel about lesbians, but a good and brave novel about a transgendered person: Jay Prosser advances this sort of view in Second Skins, and I think H. for example holds it.) ${ }^{101}$ I don't think these readings are wrong by any means ... but ...

What do we want from a theory, anyhow? Perhaps the richest and most enduring theories are those that, far from legislating a single outcome for a single moment in time and space make it possible to think ... more than one thing, in more than one way?

101 Jay Prosser, Second Skins: The Body Narratives of Transsexuality. 